\title{
Autoimmune Haemolytic Anaemia (AIHA) Secondary to Yersinia enterocolitica Septicemia: The Second Case Reported in the Literature
}

\author{
Rui Gonçalves Fernandes, Francisco Barreto, Ana Carolina Henriques, Maria Inês Correia \\ Hospital Dr. Nélio Mendonça - SESARAM, EPERAM, Funchal, Portugal
}

Doi: 10.12890/2022_003163 - European Journal of Case Reports in Internal Medicine - @ EFIM 2022

Received: 02/01/2022

Accepted: $12 / 01 / 2022$

Published: 02/02/2022

How to cite this article: Gonçalves Fernandes R, Barreto F, Henriques AC, Correia MI. Autoimmune haemolytic anaemia (AlHA) secondary to Yersinia enterocolitica septicemia: the second case reported in the literature. EJCRIM 2022;9: doi:10.12890/2022_003163.

Conflicts of Interests: The authors declare there are no competing interests.

This article is licensed under a Commons Attribution Non-Commercial 4.0 License

\section{ABSTRACT}

Yersinia enterocolitica infection is an uncommon but potentially fatal zoonosis, especially when it culminates with septicaemia. Post-infectious complications like reactive arthritis and erythema nodosum are well described in the literature. On the other hand, the association between yersinosis and autoimmune haemolytic anaemia (AIHA) has only been established in one clinical case. We present a case of an 87-year-old man admitted for AlHA, whose was successfully treated only after the identification and treatment of yersinosis.

\section{LEARNING POINTS}

- Autoimmune haemolytic anaemia is a potentially fatal condition that requires a high index of suspicion.

- Hundreds of potential causes have been described, some associated with infectious disease.

- Treatment is based on both corticosteroid therapy and treatment of the underlying condition.

\section{KEYWORDS}

Autoimmune haemolytic anaemia, Yersinia enterocolitica, yersinosis

\section{CASE DESCRIPTION}

We present the case of an 87-year-old man with history of post-traumatic splenectomy. The patient was admitted due to a 2-week history of diarrhoea followed by fever, adynamia, hypotension and painless jaundice. Laboratory tests showed immunohaematological parameters of AlHA with haemoglobin $6.2 \mathrm{~g} / \mathrm{dl}$ (normal range 13.7-17.3), total bilirubin $7.87 \mathrm{mg} / \mathrm{dl}$ (normal range $0.3-1.2 \mathrm{mg} / \mathrm{dl}$ ), LDH $532 \mathrm{U} / \mathrm{l}$ (normal range $0.0-246$ ), haptoglobin $45 \mathrm{mg} / \mathrm{dl}$ (normal range $30-200 \mathrm{mg} / \mathrm{dl}$ ) and positive direct and indirect Coombs' tests. Blood smear showed dacryocytes, anisocytosis and poikilocytosis. Additionally, acute phase parameters were elevated with $32 \times 10^{3}$ leukocytes (normal range $\left.4.2-10.8 \times 10^{3}\right), 80 \%$ neutrophils, and C-reactive protein $248 \mathrm{mg} / \mathrm{l}$ (normal range $<6.10 \mathrm{mg} / \mathrm{l}$ ).

After stabilization, the patient was started on intravenous glucocorticoid $1 \mathrm{mg} / \mathrm{kg}$ per day $(80 \mathrm{mg})$ and amoxicillin/clavulanic acid, but without any improvement. On the 4th day of hospitalization, blood cultures were positive for Yersinia enterocolitica. Antibiotic susceptibility testing showed resistance to amoxicillin/clavulanic acid, but sensibility to ciprofloxacin, which the patient took for 15 days. The onset of targeted antibiotic therapy was associated with clinical and analytical improvement, with resolution of haemolysis (Table 1). Alternative diagnoses were excluded during hospitalization.

After 2 years of follow-up, the patient is free from immunosuppressive therapy and there is no record of new haemolytic events or postinfectious complications. 


\begin{tabular}{|l|l|l|l|l|}
\hline & \multicolumn{1}{|c|}{ Day 1 } & \multicolumn{1}{c|}{ Day 4 } & \multicolumn{1}{c|}{ Day 8 } & \multicolumn{1}{c|}{ Day 18 } \\
\hline Leukocytes & $32 \times 10^{3}$ & $43 \times 10^{3}$ & $16 \times 10^{3}$ & $11 \times 10^{3}$ \\
\hline Neutrophils & $80 \%$ & $62 \%$ & $61 \%$ & $86 \%$ \\
\hline Haemoglobin & $6.2 \mathrm{~g} / \mathrm{dl}$ & $6.5 \mathrm{~g} / \mathrm{dl}$ & $10.2 \mathrm{~g} / \mathrm{dl}$ & $11 \mathrm{~g} / \mathrm{dl}$ \\
\hline $\begin{array}{l}\text { Total bilirubin/direct/ } \\
\text { indirect }\end{array}$ & $7.87 / 3.94 / 3.93 \mathrm{mg} / \mathrm{dl}$ & $3.81 / 1.92 / 1.89 \mathrm{mg} / \mathrm{dl}$ & $2.58 / 1.40 / 1.18 \mathrm{mg} / \mathrm{dl}$ & $1.33 / 0.93 / 0.40 \mathrm{mg} / \mathrm{dl}$ \\
\hline Lactate dehydrogenase & $525 \mathrm{U} / \mathrm{l}$ & $501 \mathrm{U} / \mathrm{l}$ & $432 \mathrm{U} / \mathrm{l}$ & $529 \mathrm{U} / \mathrm{I}$ \\
\hline Haptoglobin & $45 \mathrm{mg} / \mathrm{dl}$ & - & - & - \\
\hline C-reactive protein & $247.96 \mathrm{mg} / \mathrm{l}$ & $172.61 \mathrm{mg} / \mathrm{l}$ & $31.23 \mathrm{mg} / \mathrm{l}$ & $3.58 \mathrm{mg} / \mathrm{l}$ \\
\hline Coombs'test & Positive & - & - & Negative \\
\hline Antibiotic & Amoxicillin/clavulanic acid & Amoxicillin/clavulanic acid & Ciprofloxacin & Ciprofloxacin \\
\hline
\end{tabular}

Table 1. Evolution of laboratory data

\section{DISCUSSION}

The first case of yersinosis complicated by AlHA was described by von Knorring et al. in 1972, with no cases reported since then ${ }^{[1]}$.

Yersinosis is a bacterial zoonosis caused by two agents, Yersinia enterocolitica or Yersinia pseudotuberculosis. Domestic animals are the main reservoirs and the agents can be isolated from contaminated soil, water or food ${ }^{[2]}$. Clinically, yersinosis has two main presentations: diarrhoea or abdominal pain mimicking acute appendicitis (pseudoappendicitis).

Rarely, the infection can reach the bloodstream and the few cases described in the literature are associated with states of iron overload such as alcoholism, chronic liver disease, asplenia, thalassaemia, long-term dialysis or haemochromatosis. Other risk factors are diabetes mellitus, HIV, being elderly or immunosuppression therapy ${ }^{[3,4]}$. In contrast, post-infectious complications like reactive arthritis and erythema nodosum are very well described in the literature.

On the other hand, AIHA is an acquired cause of haemolytic anaemia. Its diagnosis is based on the presence of anaemia with reticulocytosis, elevation of LDH and bilirubin, and decreased haptoglobin, associated with a positive direct antiglobulin test (Coombs' test) ${ }^{[5]}$.

In the case described here, there was a temporal relationship between AlHA and Yersinia septicemia, with a probable causal relationship as well. Furthermore, control of haemolysis was only achieved after the infection was controlled. As far as we know, this is only the second such case to be reported in the literature.

\section{CONCLUSION}

In this report, the importance of the aetiological diagnosis of AlHA is highlighted, because treatment is based both on corticotherapy and treatment of the underlying cause.

\section{REFERENCES}

1. von Knorring J, Pettersson T. Haemolytic anaemia complicating Yersinia enterocolitica infection. Report of a case. Scand J Haematol 1972;9(2):149-152.

2. Rahman A, Bonny TS, Stonsaovapak S, Ananchaipattana C. Yersinia enterocolitica: epidemiological studies and outbreaks. J Pathog 2011;2011:239391.

3. Butler T. Yersinia species, including plague. In: Mandell GL, Douglas RG, Bennett JE, editors. Principles and practice of infectious diseases. 5th ed. New York: Churchill Livingstone; 2000; pp. 2406-2414.

4. Cannon CG, Linnemann CC Jr. Yersinia enterocolitica infections in hospitalized patients: the problem of hospital-acquired infections. Infect Control Hosp Epidemio 1992;13(3):139-143.

5. Guillaud C, Loustau V, Michel M. Hemolytic anemia in adults: main causes and diagnostic procedures. Expert Rev Hematol. 2012;5(2):229-241 